\title{
Assessing the quality of e-government portals - the Polish experience
}

\author{
Ewa Ziemba \\ University of Economics \\ ul. 1 Maja 50, 40-287 Katowice, \\ Poland \\ Email: ewa.ziemba@ue.katowice.pl
}

\author{
Tomasz Papaj \\ University of Economics \\ ul. 1 Maja 50, 40-287 Katowice, \\ Poland \\ Email: tomasz.papaj@ue.katowice.pl
}

\author{
Danuta Descours \\ Silesia Centre of Information Society \\ ul. Powstańców 34, 40-954 Katowice, \\ Poland \\ Email: ddescours@e-slask.pl
}

\begin{abstract}
The transition from a government to e-government poses continuous challenges in employing increasingly sophisticated web portals as the gateway to government units, their information and services. The high quality of those portals is needed for the successful adoption of e-government. Therefore, the aim of this study is to assess quality of selected Polish e-government portals based on a proposed framework. This framework employs the International Organisation for Standardisation (ISO) standard. Firstly, the paper presents various definitions of quality and different theories/models for assessing the quality of e-government portals. Secondly, the framework for assessing the quality of e-gov portals is presented. Thirdly, the assessment of Polish e-government portals based on the proposed framework is shown. The paper concludes with a discussion of research findings and recommendations for studies on e-gov portals' evaluation. Finally, the future works are submitted. The obtained research findings will prove to be helpful for researchers in developing studies on e-government, especially in the research issue of egov portals. Moreover, they can be useful while undertaking empirical activities aimed at the e-government adoption.
\end{abstract}

\section{INTRODUCTION}

$\mathrm{T}$ HE research on e-government has a relatively short history. Analyzing the three most known bibliographic databases, that are EBSCO, ISI Web of Knowledge and Scopus, reveals that scientists have started exploring e-government research since the mid 1990s. By contrast, practical e-government initiatives have been launched since the late 1990s [1]. The European Union countries, including Poland, have written into their strategic planning the building of e-government since 1999 [2], [3], [4], [5], [6], [7], [8], [9]. Studies and empirical activities aimed at e-government have strongly been developing from 2000 .

Generally, e-government means using information and communication technologies (ICTs) for [10], [11], [12], [13], [14]:

- supporting processes in government units;

- delivering e-government services at different levels of maturity to government stakeholders (i.e. citizens, enterprises and government units);

- improving government transparency, citizen's participation, and democratic decision making; and

- cooperation, networking, and maintaining partnership relations between government stakeholders.

Studies on e-government focus on the variety of issues relating to the above picture of e-government. They look at e-government from different angles. An important research issue relates to e-government maturity [15], [16], [17]. The maturity levels of e-government reveal the degree of technological sophistication and the degree of organizational transformation in a government. They reflect how enterprises and citizens can interact with government units and how government units can cooperate and communicate. The European model of e-government maturity is comprised of the following levels: information, one-way interaction (downloadable application forms), two-way interaction (electronic application forms, e-forms), transaction (full electronic) and personalization (targetisation/automation) [18], [19], [20]. E-government services (e-gov services) are another important issue of e-government research. Those services are investigated from different perspectives, e.g. their implementation [21], [22], [23] and acceptance by all government stakeholders [15], [24]. Furthermore, researchers are investigating factors that play key roles in successful adoption of e-government [25], [26], [27], [28], [29], [30], [31], [32], [33], [17]. Additionally, studies focused on implementation and acceptance of e-government portals (e-gov portals, e-government web sites) are carried out [34], [35], [36]. E-gov portals provide a single point of access to government services via the Web-enabled interface. Such portals deliver convenient online access to egov services for government stakeholders. Thanks to them, enterprises and citizens can interact with government units as well as government units can cooperate and communicate. Therefore, e-gov portals strongly influence successful adoption of e-government [36].

A review of the literature on e-gov portals reveals that research on evaluating them and assessing their quality is very limited. To address this gap, this paper aims to assess the quality of selected Polish e-gov portals based on a comprehensive framework. This framework employs the International Organisation for Standardisation (ISO) standard.

This paper is structured as follows. Firstly, the paper presents various definitions of quality and different theories/models for assessing the quality of e-gov portals. Secondly, the framework for assessing the quality of e-gov portals is presented. Thirdly, the evaluation of Polish e-gov portals based on the proposed framework is shown. The paper concludes with a discussion of research findings and recommendations for studies on e-gov portals' evaluation. Finally, the future works are submitted. 


\section{THEORETICAL BACKGROUND}

\section{A. Quality of e-government portals}

The term "quality" means characteristic, feature, trait. It rarely relates to one thing or a phenomenon. Often, it refers to a sum of these characteristics against requirements. There is not a single definition of quality. The reason is that quality is basically only "the perception of quality" [37]. Many known experts have contributed to comprehensive quality definitions.

Garvin [38] defined and Kitchenham and Pfleeger [39] expanded five different perspectives on quality:

- The transcendental perspective tackles the metaphysical aspect of quality. From this standpoint, it is "something toward which we strive as an ideal, but may never implement completely;"

- The user perspective pertains to the suitability of the product for a stated context of use. In comparison, the transcendental view is volatile, the user view is more specific, based on the product attributes that satisfy user's needs;

- The manufacturing perspective indicates quality as conformable with requirements. This view of quality is stressed by ISO 9000, which defines quality as "the degree to which a set of inherent characteristics fulfills requirements" [40];

- The product perspective indicates that quality can be acknowledged by measuring the intrinsic attributes of the product; and

- The value-based perspective assumes that the different perspectives of quality may be approached differently by various stakeholders, especially with regard to its importance or value.

Quality is relevant for both products and services. This just refers to issues of the e-gov portals quality. The American Society for Quality perceives quality as "the totality of features and characteristics of a product or service that bear its ability to satisfy stated or implied needs" [41, p. 615]. Griffin referred to basic dimensions explored by Garvin, which determine the quality of a particular product or services. These dimensions are: performance, features, reliability, conformance, durability, serviceability, aesthetic, and perceived. For Juran quality is "fitness for use", and Deming believed that "quality should be aimed at the needs of the customer, present and future." Crosby said that quality is "conformance to requirement" [37]. Feigenbaum defined quality as "a customer determination based upon a customer's actual experience with a product or service, measured against his or her requirements - stated or unstated, conscious or merely sensed, technically operational or entirely subjective - and always representing a moving target in a competitive market" [42, p. 1].

In this research the quality of e-gov portals is considered as software product quality. However, a straightforward definition for software product quality is difficult to formulate. Depending on who is evaluating the quality of software product it can be either good or bad. For instance, to an end user, if a software product offers efficient and necessary functionalities to perform the task it was developed for, then software quality is good. A different perspective may have a software developer for whom maintainability or testability, how easy it is to maintain and eliminate bugs, are the main attributes of a good quality software product. And finally, a software architect can perceive good software quality from, for example, the angle of the reusability of the used software components or the scope and quality of the descriptive literature of the software product.

\section{B. Models for assessing the quality of e-government portals}

Approaches to assessing the quality of e-gov portals have been explored for a few years [43], [44], [45], [46], [47]. In the work on them, researchers indeed mainly examined, improved and adopted models, such as D\&M [48], [49], [50], [51], TAM [52] and Wang's [53].

More generally, a framework for assessing the quality of egov portals covers three aspects of quality: system, information and service quality. System quality can be viewed as a measure of e-gov portals' functionalities. It is comprised of four constructs: usability, responsiveness, ease of access and privacy. Information quality is defined as the measure of the value which the information provides to a user. More specifically information quality can be described by four constructs: accuracy, dependability, coverage and ease of use. Service quality focuses on four others: empathy, interactivity, playfulness and aesthetic [36].

Wang and Liao [46] conducted an empirical test of D\&M model adoption in the context of G2C e-government in Taiwan. Except for the link from System Quality to System Use, the hypothesized relationships between the six success variables were significantly or marginally supported by the data. The authors emphasized that "researchers can also use the validated model as the foundation for developing comprehensive e-government systems success measures and theories, exploring relationships between the proposed constructs, and comparing e-government success empirical studies" [46].

Almalki, Duan and Frommholz [43] suggested a conceptual framework for assessing e-gov portals' success which integrates the updated D\&M model, TAM, selfefficacy theory and perceived risk. In this model 13 constructs are indentified for measuring success of e-gov. portals. Those are: system quality, information quality, service quality, computer self-efficacy, perceived risk, personal values, perceived usefulness, perceived ease of use, attitude towards using, behavior intention to use, user satisfaction, net benefits.

The next model is guided by both TAM, D\&M model and the policies framed by the government of India. It includes dimensions for assessing e-service quality of government portals, such as quality dimensions: citizen centricity, usability, technical adequacy, privacy and security, usefulness of information, transaction transparency, comprehensive information, interaction [44]. 
Papadomichelaki and Mentzas conceptualized an e-government service quality model, eGovQual, where they indicate six constructs: ease of use, trust, functionality of the interaction environment, reliability, content and appearance of information, interactivity interaction [44].

Some researchers showed that navigation facility and accessibility are important in determining citizens' perceived system quality. Whereas information preciseness, timeliness, and sufficiency were found to be key measures in information quality in government e-services [54].

\section{Basis of proposed framework for assessing the quality of e-government portals}

The proposed framework for assessing the quality of e-gov portals is primarily built on the ISO/IEC 25010 [55]. This standard was chosen because of its breadth and completeness, and because of the prestige of the organization.

According to ISO/IEC 25010, the quality of a software product is "the degree to which the system satisfies the stated and implied needs of its various stakeholders, and thus provides value" [55]. The SQuaRE series of International Standards by quality models is based on those declared and indicated needs: the quality in use model and the product quality model in this International Standard, and the data quality model in ISO/IEC 25012. In this study the product quality model was employed. It defines eight main dimensions and related sub-dimensions for assessing software products (Table 1). Factors (items, constructs, metrics) in each sub-dimension should be defined individually according to the nature of assessed software product. The stated quality factors can build a checklist for ensuring a thorough handling of quality requirements, thus founding a basis for activities that will be necessary during software product development.

The ISO/IEC 25010 software product quality model relates to four layers of quality assessment explored by Halaris et al [45]:

- back-office process performance layer, addressing factors mainly found in quality of back-office operations (this layer relates mainly to the ISO/IEC Compatibility dimension);

- portal technical performance layer, addressing the factors of the technical performance of the portal (this layer relates mainly to the ISO/IEC dimensions: Reliability, Security, Maintainability, Portability, Performance efficiency);

- portal quality layer, addressing the factors of the portal usability (this layer relates mainly to the ISO/IEC dimensions: Usability, Functional suitability); and

- customer's overall satisfaction layer, addressing the overall level of quality perceived by the user against user's expectations (this layer relates mainly to the ISO/IEC dimensions: Usability, Functional suitability, Security, Maintainability, Portability, Performance efficiency).
TABLE I.

ISO/IEC 25010 SOFTWARE PRODUCT QUALITY MODEL

\begin{tabular}{|c|c|c|}
\hline $\begin{array}{c}\text { Quality } \\
\text { dimensions }\end{array}$ & $\begin{array}{c}\text { Quality } \\
\text { sub-dimensions }\end{array}$ & Description \\
\hline \multirow{3}{*}{$\begin{array}{l}\text { Functional } \\
\text { suitability }\end{array}$} & $\begin{array}{l}\text { Functional } \\
\text { completeness }\end{array}$ & \multirow{3}{*}{$\begin{array}{l}\text { The software product's } \\
\text { ability to provide functions } \\
\text { and operations which are } \\
\text { required to fulfill stated } \\
\text { and implied users' needs }\end{array}$} \\
\hline & $\begin{array}{l}\text { Functional } \\
\text { correctness }\end{array}$ & \\
\hline & $\begin{array}{l}\text { Functional } \\
\text { appropriateness }\end{array}$ & \\
\hline \multirow[b]{3}{*}{$\begin{array}{l}\text { Performance } \\
\text { efficiency }\end{array}$} & Time behavior & \multirow{3}{*}{$\begin{array}{l}\text { The software product's } \\
\text { ability to offer sufficient } \\
\text { efficiency and using } \\
\text { reasonable amount of } \\
\text { resources }\end{array}$} \\
\hline & Resource utilization & \\
\hline & Capacity & \\
\hline \multirow[t]{2}{*}{ Compatibility } & Co-existence & \multirow{2}{*}{$\begin{array}{l}\text { The software product's } \\
\text { ability to be interoperable } \\
\text { with other software } \\
\text { products }\end{array}$} \\
\hline & Interoperability & \\
\hline \multirow{6}{*}{ Usability } & $\begin{array}{l}\text { Appropriateness } \\
\text { recognisability }\end{array}$ & \multirow{6}{*}{$\begin{array}{l}\text { The software product's } \\
\text { ability to be easy to use, } \\
\text { learnable and } \\
\text { understandable }\end{array}$} \\
\hline & Learnability & \\
\hline & Operability & \\
\hline & $\begin{array}{l}\text { User error } \\
\text { protection }\end{array}$ & \\
\hline & $\begin{array}{l}\text { User interface } \\
\text { aesthetics }\end{array}$ & \\
\hline & Accessibility & \\
\hline \multirow{4}{*}{ Reliability } & Maturity & \multirow{4}{*}{$\begin{array}{l}\text { The software product's } \\
\text { ability to perform specified } \\
\text { function under specified } \\
\text { conditions for a specified } \\
\text { period of time with the } \\
\text { minimum crashes possible }\end{array}$} \\
\hline & Availability & \\
\hline & Fault tolerance & \\
\hline & Recoverability & \\
\hline \multirow{5}{*}{ Security } & Confidentiality & \multirow{5}{*}{$\begin{array}{l}\text { The software product's } \\
\text { ability to secure its internal } \\
\text { information so that no } \\
\text { unauthorized usage is } \\
\text { possible }\end{array}$} \\
\hline & Integrity & \\
\hline & Non-repudiation & \\
\hline & Accountability & \\
\hline & Authenticity & \\
\hline \multirow{5}{*}{ Maintainability } & Modularity & \multirow{5}{*}{$\begin{array}{l}\text { The software product's } \\
\text { ability to be changeable, } \\
\text { maintainable and updatable }\end{array}$} \\
\hline & Reusability & \\
\hline & Analysability & \\
\hline & Modifiability & \\
\hline & Testability & \\
\hline \multirow{3}{*}{ Portability } & Adaptability & \multirow{3}{*}{$\begin{array}{l}\text { The software product's } \\
\text { ability to be portable from } \\
\text { one software (hardware) } \\
\text { environment to another }\end{array}$} \\
\hline & Installability & \\
\hline & Replaceability & \\
\hline
\end{tabular}

Source: based on (ISO/IEC, 2011)

The third model employed in the proposed framework for assessing the quality of e-gov portals was constituted and utilized by IT Project Centre in Poland [56]. This model focuses on usability of e-gov portals and includes 96 factors grouped into the following five dimensions: interface cohesion and user friendliness, pages design, navigation, content, e-gov services form, search engine, main page. Some factors of the IT Project Centre have been used in the Usability dimension.

\section{RESEARCH METHODOLOGY}

This study is a part of research on the holistic and systems approach to the e-government adoption in the context of sustainable information society [57]. Various methods and techniques have been applied in this research at three steps: 
- The first step - a review of literature was conducted to explore various definitions of quality and different models for assessment of the e-gov portals;

- The second step - the framework for assessing quality of e-gov portals was established on the basis of literature findings, empirical observations, brainstorming and methods of creative thinking and logical deduction; and

- The third step - the pilot study (feasibility study, experimental trial) was carried out to verify and test the proposed conceptual framework. It was a smallscale, short-term experiment that helped pre-test the reliability and importance of indicated factors in assessing e-gov portals. The study was conducted in December, 2013. Three Polish e-gov portals that can be examples of "good practices" were evaluated. It was a self-assessment; each portal was evaluated by the qualified employees of the appropriate government unit. To classify each factor, the respondents had to carefully read and analyze their portal. E-gov portals' quality has been assessed on a two-point scale: 1 - the capability has been implemented correctly or the capability has been implemented partially; and 0 - the capability has not been implemented. All factors of the framework are equally important and none of them has been prioritized. The final evaluation of each portal is defined as the total sum of ratings of subsequent factors. Microsoft Excel was used to conduct the entire analysis. In the final step of our study, on the basis of creative thinking and logical deduction, recommendations on the evaluation of e-gov portals were formulated.

\section{RESEARCH FINDINGS}

\section{A. The proposed framework for assessing the quality e-government portals}

In the proposed framework, a quality of e-gov portals is understood as their capability to satisfy stated and implied needs for the e-gov portal to be used under specified conditions. The dimensions and sub-dimensions of this framework were adopted from ISO standard. For each subdimension, the capability of e-gov portals is determined by a set of factors that can be measured. 89 factors were indicated that include 14 factors within Functional suitability, 6 factors - Performance efficiency, 6 factors Compatibility, 27 factors - Usability, 11 factors Reliability, 6 factors - Security, 13 factors - Maintainability, 6 factors - Portability. Detailed enumeration of these factors is presented in [58]. The dimensions, sub-dimensions and factors are structured in the framework as shown in Table 2.

The quality of e-gov portals can be evaluated by all government stakeholders, i.e. government units, citizens and enterprises. Maintainability concentrates on government units' self-assessment, while other dimensions put emphasis on citizens' and enterprises' as well as government employees' evaluation.
TABLE II.

THE CONCEPTUAL FRAMEWORK FOR ASSESSING THE QUALITY OF E-GOV PORTALS

\begin{tabular}{|c|c|}
\hline $\begin{array}{l}\text { Dimensions/ Sub- } \\
\text { dimensions }\end{array}$ & Factors descriptions (capabilities) \\
\hline \multicolumn{2}{|c|}{ 1. Functional suitability (14 factors) } \\
\hline 1.1. Completeness & $\begin{array}{l}\text { Delivering e-gov services at the different levels } \\
\text { of maturity }\end{array}$ \\
\hline 1.2. Correctness & Correct operation of e-gov services \\
\hline 1.3. Appropriateness & $\begin{array}{l}\text { Matching e-gov services to the current and future } \\
\text { needs of stakeholders }\end{array}$ \\
\hline \multicolumn{2}{|c|}{ 2. Performance efficiency (6 factors) } \\
\hline 2.1. Time behaviour & $\begin{array}{l}\text { Shortened time required to the settlement of the } \\
\text { matter }\end{array}$ \\
\hline $\begin{array}{r}\text { 2.2. Resource } \\
\text { utilization }\end{array}$ & $\begin{array}{l}\text { Reducing consumption of resources (e.g. paper, } \\
\text { toner), decrease in employment in government } \\
\text { units; reduction in various transaction costs }\end{array}$ \\
\hline 2.3. Capacity & $\begin{array}{l}\text { Lack of restrictions for users while using portal } \\
\text { (e.g. time, number of documents); swift loading } \\
\text { and running }\end{array}$ \\
\hline \multicolumn{2}{|c|}{ 3. Compatibility (6 factors) } \\
\hline 3.1. Co-existence & $\begin{array}{l}\text { Integration between portal, back-office systems } \\
\text { and other e-gov portals; updated specification } \\
\text { sheet comprising necessary information to } \\
\text { integrate portal with other systems and portals }\end{array}$ \\
\hline 3.2. Interoperability & $\begin{array}{l}\text { Unified and consistent layout and content of } \\
\text { mandatory information about government units } \\
\text { and e-gov services; standardized electronic forms } \\
\text { for all e-gov services }\end{array}$ \\
\hline \multicolumn{2}{|c|}{ 4. Usability (27 factors) } \\
\hline $\begin{array}{l}\text { 4.1. Appropriateness } \\
\text { recognisability }\end{array}$ & $\begin{array}{l}\text { Different assistance methods for users, e.g. help } \\
\text { module, assistance available at every level of } \\
\text { portal use, electronic courses, wizard for filling } \\
\text { out electronic forms, advanced search engine } \\
\text { accessible from every level of portal use, virtual } \\
\text { adviser }\end{array}$ \\
\hline 4.2. Learnability & Intuitive operating of portal \\
\hline 4.3. Operability & $\begin{array}{l}\text { Site map; at any time users know where they are } \\
\text { and may return to any portal page at any time; } \\
\text { not more than nine submenu level created for a } \\
\text { menu }\end{array}$ \\
\hline $\begin{array}{l}\text { 4.4. User error } \\
\text { protection }\end{array}$ & $\begin{array}{l}\text { Portal is protected against admitting wrong } \\
\text { (incorrect) data; users are kept informed on the } \\
\text { errors and the need to correct them; suggestions } \\
\text { for users how to improve errors }\end{array}$ \\
\hline $\begin{array}{l}\text { 4.5. User interface } \\
\text { aesthetics }\end{array}$ & $\begin{array}{l}\text { Defining the look of portal by users; portal pages } \\
\text { are divided into clear blocks (sections); } \\
\text { consistent layout and navigation on pages; } \\
\text { highlighted important information (e.g. names of } \\
\text { sections, names of e-gov services, names of } \\
\text { government units); clearly formatted contents of } \\
\text { pages; graphic signs (icons) facilitating portal } \\
\text { use; clear and understandable descriptions of e- } \\
\text { gov services; comprehensible electronic forms } \\
\text { for e-gov services }\end{array}$ \\
\hline 4.6. Accessibility & $\begin{array}{l}\text { Adjusting font sizes to users requirements; } \\
\text { special version of portal for the visually impaired } \\
\text { and the blind; foreign language versions of portal }\end{array}$ \\
\hline \multicolumn{2}{|c|}{ 5. Reliability (11 factors) } \\
\hline 5.1. Maturity & $\begin{array}{l}\text { Portal is protected against non-standard behavior } \\
\text { of users; certified information security }\end{array}$ \\
\hline
\end{tabular}




\begin{tabular}{|c|c|}
\hline $\begin{array}{l}\text { Dimensions/ Sub- } \\
\text { dimensions }\end{array}$ & Factors descriptions (capabilities) \\
\hline & $\begin{array}{l}\text { management system according to PN-ISO/IEC } \\
\text { 27001:2007 standard has been implemented }\end{array}$ \\
\hline 5.2. Availability & $\begin{array}{l}\text { Portal accessible to the users } 7 \text { days a week and } \\
24 \text { hours a day; failure-free of portal working; } \\
\text { delivering information on planned breaks in } \\
\text { portal operations }\end{array}$ \\
\hline 5.3. Fault tolerance & $\begin{array}{l}\text { In the event of non-critical errors on the portal, } \\
\text { its other functions can still be used; in case of } \\
\text { errors when sending the completed application } \\
\text { form - the application is saved and it is available } \\
\text { to the user after the next login }\end{array}$ \\
\hline 5.4. Recoverability & $\begin{array}{l}\text { There is procedures in cases of portal failure to } \\
\text { recover portal after failures and to create the } \\
\text { archive data entered through the portal; there is a } \\
\text { redundant portal (replacement) in the event of } \\
\text { failure }\end{array}$ \\
\hline \multicolumn{2}{|l|}{ 6. Security (6 factors) } \\
\hline 6.1. Confidentiality & $\begin{array}{l}\text { Users password is masked; required cyclical } \\
\text { change of the password by users; encrypted the } \\
\text { connection with the portal }\end{array}$ \\
\hline 6.2. Integrity & There is a procedure of data protection \\
\hline 6.3. Non-repudiation & For the study was combined with Accountability \\
\hline 6.4. Accountability & $\begin{array}{l}\text { All of the actions on the portal are identifiable by } \\
\text { the user (e.g. first name, surname) and the time } \\
\text { when an action was completed (making history } \\
\text { of actions undertaken) }\end{array}$ \\
\hline 6.5. Authenticity & $\begin{array}{l}\text { Checking the complexity of the users' passwords } \\
\text { from the viewpoint of safety standards }\end{array}$ \\
\hline \multicolumn{2}{|c|}{ 7. Maintainability (13 factors) } \\
\hline 7.1. Modularity & $\begin{array}{l}\text { Modular construction of portal; updated } \\
\text { specification sheet of relationships between } \\
\text { portal modules }\end{array}$ \\
\hline 7.2. Reusability & $\begin{array}{l}\text { Portal modules implemented in its different parts } \\
\text { or other portals }\end{array}$ \\
\hline 7.3. Analysability & $\begin{array}{l}\text { Easy analysis for change of modules and its } \\
\text { impact on other modules or other integrated } \\
\text { portals; informing about changes of module that } \\
\text { affect other modules or integrated portals }\end{array}$ \\
\hline 7.4. Modifiability & $\begin{array}{l}\text { Portal's functionalities can be modified and } \\
\text { extended according to users' new needs and in } \\
\text { accordance with the new letter of the law; users } \\
\text { are informed about the availability of new portal } \\
\text { functionalities }\end{array}$ \\
\hline 7.5. Testability & $\begin{array}{l}\text { There are: a portal test environment, procedures } \\
\text { for portal testing, procedures for changes of the } \\
\text { production version of portal, procedures for } \\
\text { returning to the previous version of portal; } \\
\text { subsequent versions of portal are identifiable }\end{array}$ \\
\hline \multicolumn{2}{|c|}{ 8. Portability (6 factors) } \\
\hline 8.1. Adaptability & $\begin{array}{l}\text { There is a mobile version of portal; portal can be } \\
\text { used by any web browser and by any operating } \\
\text { system }\end{array}$ \\
\hline 8.2. Installability & $\begin{array}{l}\text { Use of portal does not require the purchase of } \\
\text { specialist software and the installation of special } \\
\text { software }\end{array}$ \\
\hline 8.3. Replaceability & $\begin{array}{l}\text { Users are informed about the need to install the } \\
\text { free software and its new version necessary for } \\
\text { the proper functioning of the portal }\end{array}$ \\
\hline
\end{tabular}

\section{B. Assessing the quality of e-government portals using the proposed framework}

The cases of Polish e-government portals

Three Polish e-gov portals that can be examples of "good practices" were evaluated by using this framework. Those were: SEKAP (www.sekap.pl), Digital Malopolska (http://www.wrotamalopolski.pl) and the Gate of Podlasie (http://cu.wrotapodlasia.pl). Currently, all these portals are being improved and this research can help the local government authorities to manage improvement activities.

SEKAP is a result of strategic, innovative projects, that were carried out by the municipal and district authorities of the Silesian Voivodeship in 2005-2008 and 2009-2012 [13], [20]. It enables the provision of e-gov services, including five forms of the relations between government units and their stakeholders: $\mathrm{C} 2 \mathrm{G} / \mathrm{G} 2 \mathrm{C}, \mathrm{B} 2 \mathrm{G} / \mathrm{G} 2 \mathrm{~B}, \mathrm{G} 2 \mathrm{G}$. The egovernment services are provided at different levels of maturity, from the information level to the transaction level. Currently, 122 government units provide e-gov services through SEKAP to citizens, enterprises and other government units. SEKAP includes different kinds of 650 various e-gov services, while the number e-gov services delivered by an individual government unit is 27,264 .

Digital Malopolska is a result of a strategic, innovative project that was carried out by the municipal and district authorities of the Lesser Poland (Malopolska) Voivodeship in 2004-2006. The e-gov services for government stakeholders are provided at different levels of maturity, from the information level to the transaction level. Currently, 187 government units provide e-gov services through Digital Malopolska to citizens, enterprises and other government units. Digital Malopolska includes different kinds of 128 various e-gov services, while the number e-gov services delivered by an individual government unit is 23,936.

The Gate of Podlasie is a result of a strategic, innovative project that was carried out by the municipal and district authorities of the Podlaskie Voivodeship and ended in 2006. The e-gov services are provided at different levels of maturity, from the information level to the transaction level. Currently, 97 government units provide e-gov services through the Gate of Podlasie to citizens, enterprises and other government units. The Gate of Podlasie includes different kinds of 1,060 various e-gov services, while the number e-gov services delivered by an individual government unit is 3,000. Currently, this e-gov portal is under reconstruction.

\section{Assessing Functional suitability}

All examined e-gov portals received very low scores in Functional suitability dimension (Figure 1). This mainly results from incomplete catalogue of e-gov services at the appropriate levels of maturity. In both cases of Digital Malopolska and the Gate of Podlasie the users of the portals pointed out at some malfunctions of the available e-gov services and the need to deliver new ones. Correct operation of the available e-gov services and the need to create new e- 


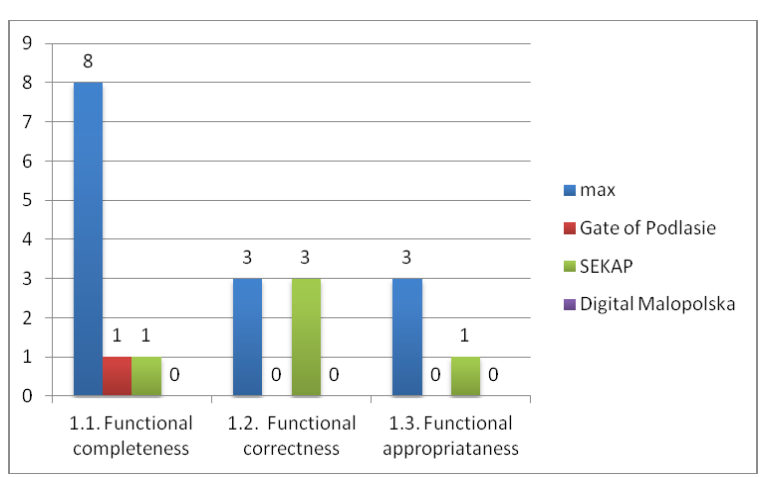

Fig. 1. Assessing Functional suitability of the Polish e-gov portals

gov services were reported by e-gov employees to the SEKAP portal.

\section{Assessing Performance efficiency}

In Performance efficiency dimension, Digital Malopolska, received $-83 \%$ of all points, SEKAP $-67 \%$, the Gate of Podlasie $-33 \%$ (Figure 2). All respondents indicated that the time of settling the matter initiated electronically is not shorter than of the matter initiated in a traditional way. Moreover, in both cases of Digital Malopolska and SEKAP there was smaller consumption of resources (paper, toner, etc.) and lower costs when dealing electronically than traditionally. In addition, in the case of these two portals there are no restrictions on their use, and government stakeholders did not report their observations on their operation being too slow.

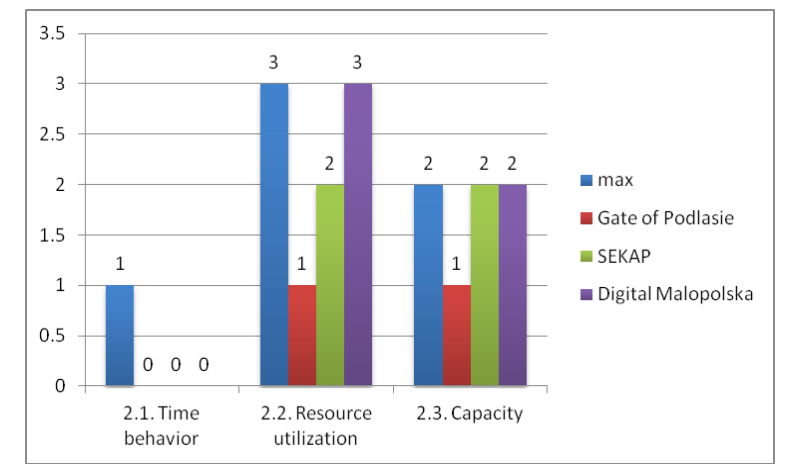

Fig. 2. Assessing Performance efficiency of the Polish e-gov portals

\section{Assessing Compatibility}

Digital Malopolska and SEKAP received $100 \%$ points in Compatibility dimensions, the Gate of Podlasie - 67\% (Figure 3). All portals are integrated with different e-gov portals and back-office information systems (including different document management systems). Moreover, the documentation required to complete the integration is available. On all examined e-gov portals, information on egov services, information about e-government units and application forms is standardized.

\section{Assessing Usability}

Digital Malopolska received $85 \%$ of all points in Usability dimension, SEKAP - 74\%, the Gate of Podlasie $56 \%$ (Figure 4). All examined e-gov portals have help

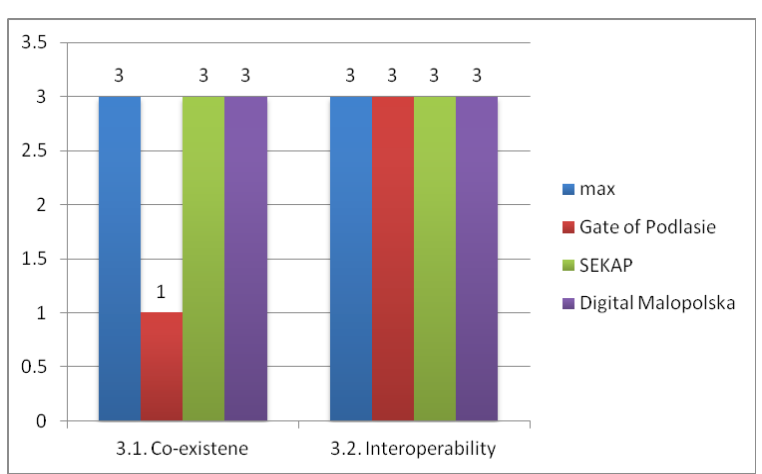

Fig. 3. Assessing Compatibility of the Polish e-gov portals

modules, providing assistance when filling out forms, and informing users about the errors made by them. They are protected against admitting wrong (incorrect) data. All examined e-gov portals have intuitive interface, easy navigation systems, not more than nine menu (submenu) levels. Only Digital Malopolska makes a portal map and elearning on using the portal available. The portals do not have virtual advisers, and do not allow users to configure the layout of any portal (customization). Also, none of the portals is accessible for the blind, they do not offer voice messages, and there are also no foreign language versions of the portals.

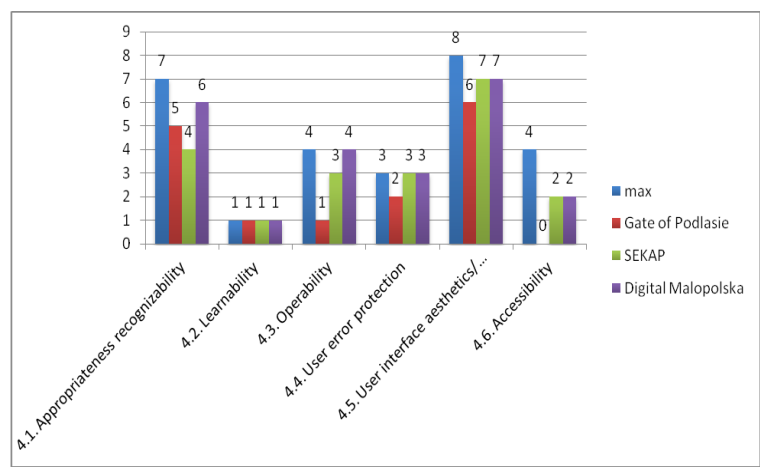

Fig. 4. Assessing Usability of the Polish e-gov portals

\section{Assessing Reliability}

SEKAP and Digital Malopolska received 91\% of all points in Reliability dimension, the Gate of Podlasie - 73\% (Figure 5). All portals are protected against non-standard behavior of users. It is worth emphasizing that the government units providing e-gov services on SEAKP and Digital Malopolska implemented certified information security management systems according to PN-ISO/IEC 27001:2007 [59]. All portals are accessible to users 7 days a week and 24 hours a day. Moreover, information on planned breaks in portals operations is delivered. In the event of non-critical errors on the portals, their other functions can still be used. There are procedures in cases of portals failures; to recover portals after failures and to create the archive data entered through the portals. SEKAP does not have a redundant portal (replacement) in the event of failure, while Digital Malopolska does not provide the re-send request after the failure of the portal. 


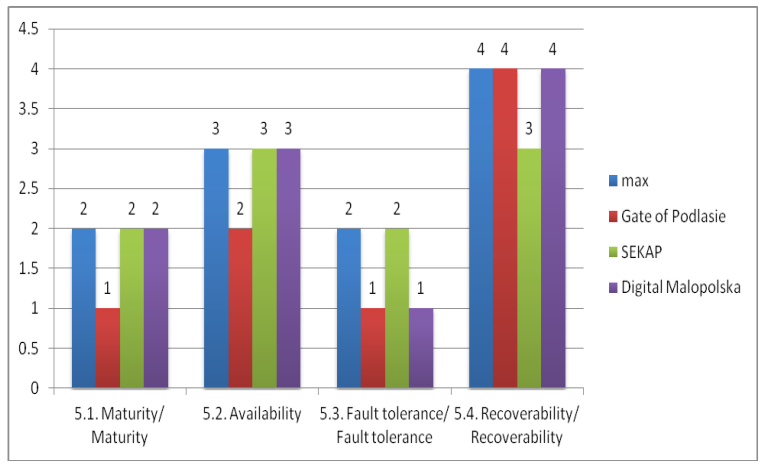

Fig. 5. Assessing Reliability of the Polish e-gov portals

\section{Assessing Security}

In Security dimension, Digital Malopolska received 100\% of all points, whereas the Gate of Podlasie and SEKAP $83 \%$ (Figure 6). Users' passwords are masked and the connection with the portals is encrypted. SEKAP and the Gate of Podlasie do not enforce the cyclical change of the password to the user's accounts. For all portals, procedures of data protection have been drawn. All of the actions on the portals are identifiable by the user (e.g. first name, surname) and the time when actions were completed. The complexity of the users' passwords from the viewpoint of safety standards is checked on the portals.

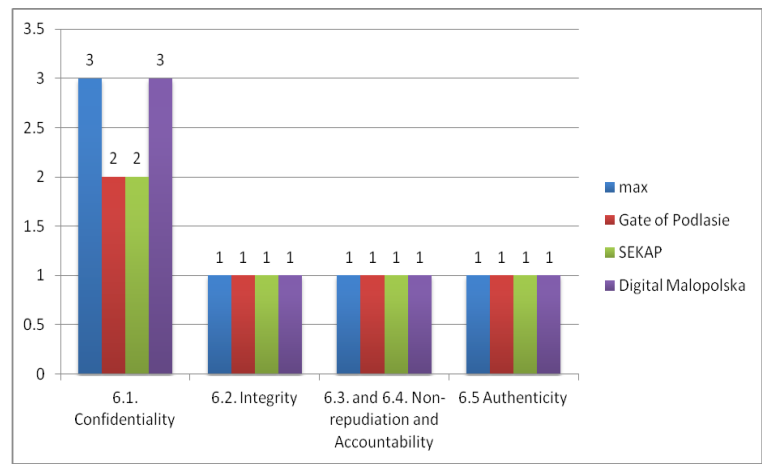

Fig. 6. Assessing Security of the Polish e-gov portals

\section{Assessing Maintainability}

In Maintainability dimension, Digital Malopolska received $100 \%$ of all points, SEKAP $-92 \%$ and the Gate of Podlasie $-31 \%$ points (Figure 6 ). All portals are made of modules and there are updated specification sheet of relationships between portal modules. Furthermore, the functionalities of the portals can be modified and extended according to users' new needs and in accordance with the new letter of the law.

\section{Assessing Portability}

In Portability dimension, Digital Malopolska received $83 \%$ of all points, whereas the Gate of Podlasie and SEKAP - 67\% (Figure 7). All portals can be used by any web browser and by any operating system. There are not mobile versions of SEKAP and the Gate of Podlasie. The use of

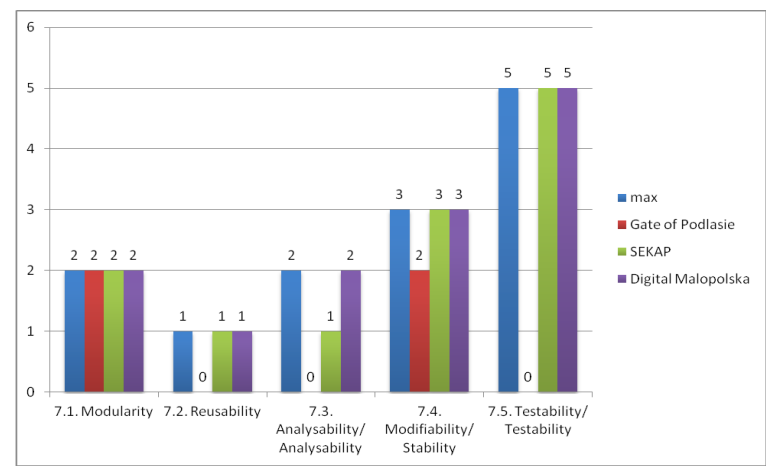

Fig. 7. Assessing Maintainability of the Polish e-gov portals

portals does not require the purchase of specialist software and the installation of special software.

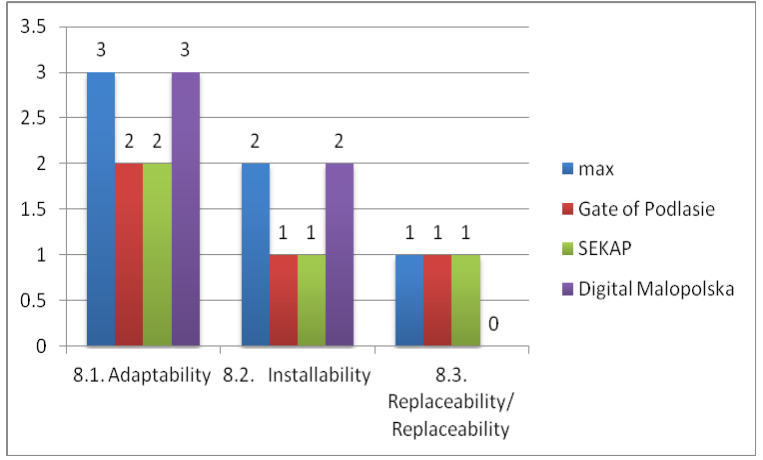

Fig. 8. Assessing Portability of the Polish e-gov portals

Overall assessing the quality of the Polish e-government portals

The study showed that Digital Malopolska portal meets the factors identified in the proposed framework $(76 \%)$ to the greatest extent, the next one is SEKAP (74\%), and the last the Gate of Podlasie (48\%). All in all, out of 89 points, the examined e-gov portals received sequentially $-68,66$ and 43 points (Figure 8). The lowest position of the Gate of Podlasie portal may be the result of its reconstruction. The portals have received the highest notes in Compatibility, Reliability, Security and Portability dimensions. They have been assessed worst in Functional suitability.

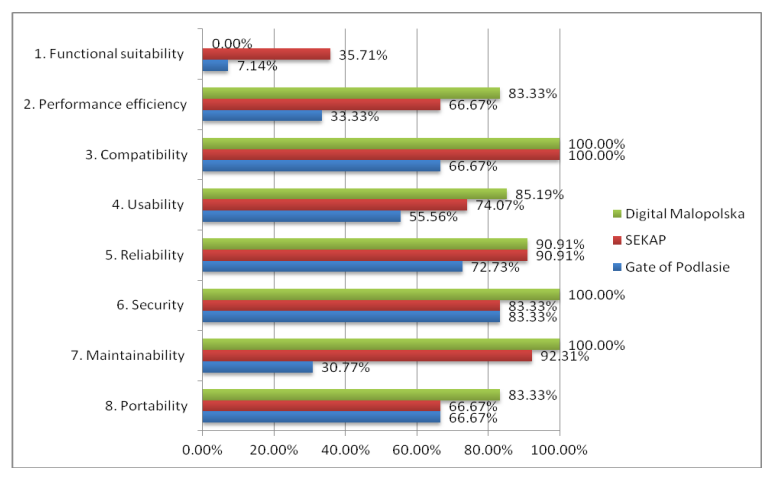

Fig. 9. The total assessment of Polish e-gov portals 


\section{V.CONCLUSION}

So, in this paper a framework for the quality evaluation of e-gov portals based on International Organisation for Standardisation (ISO) standard is proposed. The aims of this research were to build a framework for a quality evaluation of e-gov portals and employ it in comparing three popular Polish e-gov portals. This framework can become a platform for developing a quality assessment of e-gov portals. Additionally, this work contributes to extant research by suggesting a framework based on ISO standard. The ISO was chosen because of its breadth and completeness, and because of its prestige.

Evaluation of three Polish e-gov portals confirmed each of the eight dimensions i.e. Functional suitability, Performance efficiency, Compatibility, Usability, Reliability, Security, Maintainability and Portability can be a good measure for e-gov portals quality. The identified factors measure the quality of e-gov portals from different points of views. At the same time, they show how e-gov portals should be improved.

This study provides several implications for research and empirical activities. It indicates an instrument which can identify the e-gov portals' features that are important for their quality. Researchers and scholars who develop studies on e-gov portals evaluation could find significant guidelines in this paper. They can use the instrument more confidently in their own research on e-gov portals and the successful egov adoption. Moreover, for practitioners, the results of this study can be used to undertake empirical activities aimed at evaluation and improvement of e-gov portals. Moreover, the framework can constitute important support for the procurement processes. The specified factors can be used to create the terms of reference for e-gov portal projects.

One limitation of this study was the small sample size, which is a concern because of reliability and validity issues. While this did not constrain the data analysis, a larger and more representative sample may yield more useful results. Another limitation was the verified and tested framework by e-gov employees only, while some factors of Functional suitability, Performance efficiency and Usability should be evaluated by citizens and enterprises. The third limitation was the two-point scale of evaluation, while generally the level of capabilities implementation should be measured. However, this study helps provide some insights that can lead to improvement of e-gov portals, not only in Poland but also in other countries.

The research will be continued. On the basis of the pilot study findings the factors will be modified and extended in each dimension, and Likert scale will be applied before launching a larger study. The theoretical and methodological paradigm of this research will be in-depth explored and the verification will be conducted on the example of Polish and other countries' e-gov portals.

\section{ACKNOWLEDGEMENTS}

This research has been supported by a grant entitled "Designing a system approach to sustainable development of the information society - on the example of Poland" from the National Science Centre in Poland, 2011/01/B/HS4/00974, 2011-2014.

\section{REFERENCES}

[1] O. Almalki, Y. Duan and I. Frommholz, "Developing a conceptual framework to evaluate e-government portals' success," in Proceedings of the 13 European Conference on e-Government, University of Insubria, E. Ferrari, W. Castelnovo, Eds. Varese Italy, 13-14 June, 2013, 1, pp. 19-26.

2] COM (1999) 687 final, eEurope - An Information Society For All, Communication of 8 December 1999 on a Commission initiative for the special European Council of Lisbon, 23 and 24 March 2000, retrieve from: http://europa.eu/legislation_summaries/information society/strategies/index_en.htm, 2012.

[3] COM (2001) 140 final, eEurope 2002: Impact and Priorities, Commission Communication of 13 March 2001 on a Communication to the Spring European Council in Stockholm, 23 and 24 March, retrieve from: http://europa.eu/legislation_summaries /information society/strategies/index en.htm, 2012

[4] COM (2003) 567, The Role of eGovernment for Europe's Future, Communication of 26 September 2003 from the Commission to the Council, the European Parliament, the European Economic and Social Committee and the Committee of the Regions, retrieve from: http://europa.eu/legislation_summaries/information_society/strategies /index en.htm, 2012.

[5] COM (2006) 173 final, i2010 eGovernment Action Plan Accelerating eGovernment in Europe for the Benefit of All, retrieve from:

http://europa.eu/legislation_summaries/information_society/strategies /index en.htm, 2012.

[6] COM (2010) 245, A Digital Agenda for Europe, Communication from the Commission of 19 May 2010 to the European Parliament, the Council, the European Economic and Social Committee and the Committee of the Regions, retrieve from: http://europa.eu/legislation _summaries/information_society/strategies/index_en.htm, 2012.

[7] COM (2010) 2020 final, EUROPE 2020 A Strategy for Smart, Sustainable and Inclusive Growth, European Commission, retrieve from:http://europa.eu/legislation summaries/information_society/stra tegies/index en.htm, 2012.

[8] MSWiA (2008), Strategia Rozwoju Społeczeństwa Informacyjnego w Polsce do roku 2013, Warszawa: Ministerstwo Spraw Wewnetrznych i Administracji, 2008, retrieve from: http://www.mswia.gov.pl/ strategia/, 2010.

[9] Sejmik (2009), Strategia Rozwoju Społeczeństwa Informacyjnego Województwa Ślaskiego do roku 2015, Katowice: Uchwała nr III/37/2/2009 Sejmiku Województwa Śląskiego, 2009.

[10] A. V. Anttiroiko, "A brief introduction to the field of e-government," in Electronic Government: Concepts, Methodologies, Tools, and Applications, A. V. Anttiroiko, Ed. New York: Hershey, 2008, pp. xlilxxv.

[11] H. Michel, "E-administration, e-government, e-governance and the learning city: A typology of citizenship management using ICTs," The Electronic Journal of e-Government, vol. 3, no. 4, pp. 213-218, 2005.

[12] J. R. Gil-García and N. Helbig, "Exploring e-government benefits and success factors," in Encyclopedia of Digital Government, A. V. Anttiroiko and M. Mälkiä, Eds., Hershey: Idea Group Reference, vol. 2, pp. 803-811, 2007.

[13] E. Ziemba and T. Papaj, "E-government Application at the Regional Level in Poland - the Case of SEKAP," in Proceedings of the Federated Conference on Computer Science and Information Systems, Wrocław, 9-12 September 2012, pp. 1075-1082.

[14] E. Ziemba, T. Papaj, and R. Żelazny, "A model of success factors for e-government adoption - the case of Poland," Issues in Information Systems, vol. 14, no. 2, pp. 87-100, 2013.

[15] M. Kachwamba and A. Hussein, "Determinants of e-government maturity: Do organizational specific factors matter?," Journal of USChina Public Administration, vol 6, no.7 (Serial No.50), pp.1-8, 2009.

[16] T. Almarabeh and A. AbuAli, "A general framework for e-government: definition maturity challenges, opportunities, and success," European Journal of Scientific Research, vol.39, no.1, pp. 29-42, 2010.

[17] P. Ifinedo and M. Singh, "Determinants of eGovernment maturity in the transition economies of Central and Eastern Europe," Electronic Journal of e-Government, vol. 9, issue 2, pp. 166-182, 2011. 
[18] The User Challenge Benchmarking the Supply of Public Services - 7th Measurement, September 2007, European Commission, Directorate General for Information Society and Media, Diegem, 2007.

[19] Digitizing Public Services in Europe: Putting Ambition into Action, 9th Benchmark Measurement, European Commission, CapGemini, Rand Europe, 2010.

[20] E. Ziemba and T. Papaj, "A Pragmatic approach to the e-government maturity in Poland - implementation and usage of SEKAP," in Proceedings of European Conference on eGovernment, University of Insubria, Como, 2013, pp. 560-570.

[21] S. al Shafi and V. Weerakkody, "Understanding citizens' behavioural intension in the adoption of e-government services in the state of Qatar," in Proceedings $17^{\text {th }}$ European Conference on Information Systems, 2009, p.1-13.

[22] S. Angelopoulos, F. Kitsios and T. Papadopoulos, "New service development in e-government: identifying critical success factors," Transforming Government: People, Process and Policy, vol. 4, issue 1 , pp. $95-118,2010$.

[23] S. C. Srivastava, "Is e-government providing the promised returns?: A value framework for assessing e-government impact," Transforming Government: People, Process and Policy, vol. 5, issue 2, pp.107-113, 2011.

[24] S. C. Srivastava, "Is e-government providing the promised returns? A value framework for assessing e-government impact," Transforming Government: People, Process and Policy, vol. 5, issue 2, pp. 107 $113,2011$.

[25] S. Marche and J. D. McNiven, "E-government and e-governance: the future isn't what it used to be," Canadian Journal of Administrative Science, vol. 20, no. 1, pp. 74-86, 2003.

[26] R. M. Davison, C. Wagner and L. C. K. Ma, "From government to egovernment: a transition model," Information Technology \& People, vol. 18 , no. 3 , pp. $280-299,2005$.

[27] J. Choudrie, V. Weerakkody and S. Jones, "Realising e-government in the UK: rural and urban challenges," Journal of Enterprise Information Management, vol. 18, no. 5, pp. 568-585, 2005.

[28] Z. Kovacic, "The impact of national culture on worldwide egovernment readiness," Informing Science, 8, pp. 143-158, 2005.

[29] M. Asgarkhani, "Digital government and its effectiveness in public management reform: A local government perspective," Public Management Review, vol. 7, no. 3, pp. 465-487, 2005.

[30] A. Sultan, K. A. AlArfaj, and G. A. AlKutbi, "Analytic hierarchy process for the success of e-government," Business Strategy Series, vol. 13 , no. 6 , pp. 295-306, 2007.

[31] N. Letch and J. Carroll, "Excluded again: implications of integrated egovernment systems for those at the margins," Information Technology \& People, vol. 21, no. 3, pp. 283-299, 2008.

[32] E. N. Nfuka and L. Rusu, "The effect of critical success factors on IT governance performance," Industrial Management \& Data Systems, vol. 111, no. 9, pp. 1418-1448, 2011.

[33] F. Zhao, "Impact of national culture on e-government development: a global study," Internet Research, vol. 21, no. 3, pp. 362-380, 2011.

[34] E. Daniel and J. Ward, "Integrated service delivery: exploratory case studies of enterprise portal adoption in UK local government," Business Process Management Journal, vol. 12, no. 1, pp. 113-123, 2006.

[35] D. J. Calista and J. Melitski, "Digitized government best practices in country web sites from 2003 to 2008: the results are bifurcated," Business Process Management Journal, vol. 18, no. 1, pp. 138-162, 2012.

[36] A. Y. K. Chua, D. H. Goh and R. P. Ang, "Web 2.0 applications in government web sites: prevalence, use and correlations with perceived web site quality," Online Information Review, vol. 36, no. 2, pp. 175-195, 2012.

[37] R. Luburić, "Total quality management as a paradigm of business success," Journal of Central Banking Theory and Practice, vol. 3 , no.1, pp. 59-80, 2014.

[38] D. A. Garvin, Managing Quality - the strategic and competitive edge. New York, New York: Free Press, 1988.
[39] B. Kitchenham and SL. Pfleeger, "Software quality: the elusive target," IEEE Software, vol. 13, no. 1, pp. 12-21, 1996.

[40] ISO (2005), Quality management systems - Fundamentals and vocabulary - ISO 9000:2005.

[41] R. W. Griffin, Management, Mason, South-Western Cengage Learning, 2013.

[42] L. Wankhade and B. Dabade, Quality uncertainty and perception: information asymmetry and management of quality uncertainty and quality perception, Berlin: Springer-Verlag, 2010.

[43] O. Almalki, Y. Duan, and I. Frommholz, "Developing a conceptual framework to evaluate e-government portals' success," in Proceedings of the 13 European Conference on e-Government, E. Ferrari, W. Castelnovo, Eds. University of Insubria, 13-14 June 2013, 1, 2013, pp. 19-26.

[44] D. Bhattacharya, U. Gulla and M. P. Gupta, "E-service quality model for Indian government portals: citizens' perspective," [online], http://www.emeraldinsight.com/journals.htm?issn=1741-0398, vol. 25, no. 3, pp. 246-271, 2012.

[45] Ch. Halaris, B. Magoutas, X. Papadomichelaki and G. Mentzas, "Classification and synthesis of quality approaches in e-government services," Internet Research, vol. 17, no. 4, pp. 378-401, 2007.

[46] Y. S. Wang and Y. W. Liao, “Assessing e-government systems success: a validation of the DeLone and McLean model of information systems success," Government Information Quarterly, vol. 25, no. 4, pp. $717-733,2008$.

[47] S. K. Sharma, H. Al-Shihi and S. M. Govindaluri, "Exploriong quality of e-governmnet services in Oman," Education, Business and Society: Contemporary Middle Eastern Issues, vol. 6, no. 2, pp. 87100, 2013.

[48] W. H. DeLone and E. R. McLean, "Information systems success: the quest for the dependent variable," Information Systems Research, vol. 3, no. 1 , pp. $60-95,1992$.

[49] W. H. DeLone and E. R. McLean, "Information systems success revisited," in Proceedings of the 35th Hawaii International Conference on System Sciences IEEE Computer Society, Hawaii, US, 2002, pp. 1-11

[50] W. H. DeLone and E. R. McLean, "The DeLone and McLean model of information systems success: a ten-year update," Journal of Management Information Systems, vol. 19, no. 4, pp. 9-30, 2003.

[51] S. Petter, W. H. DeLone and E. McLean, "Measuring Information Systems Success: Models, Dimensions, Measures, and Interrelationships," European Journal of Information Systems, 17, pp. 236-263, 2008

[52] F. D. Davis, "Perceived usefulness, perceived ease of use, and user acceptance of information technology," MIS Quarterly, vol. 13, no. 3 , pp. 319-339, 1989

[53] Y.S. Wang, "Assessing e-commerce systems success: a respecification and validation of the DeLone and McLean model of IS success," Information Systems Journal, vol. 18, no. 5, pp. 529-557, 2008.

[54] P. Saha, A. K. Nath and E. Salehi-Sangari, "Evaluation of government e-tax websites: an information quality and system quality approach," Transforming Government: People, Process and Policy, vol. 6, no. 3, pp. 300-321, 2012.

[55] ISO/IEC (2011), Systems and software engineering. Systems and Software quality. Requirements and Evaluation (SQuaRE). System and software quality models. ISO/IEC 25010:2011(E), International Organisation for Standardisation, Geneva, 2011.

[56] Analysis of Good Practice in the Area of E-government (Analiza Dobrych Praktyk w Obszarze E-administracji), IT Project Center (Centrum Projektów Informatycznych), Warsaw, 2013.

[57] E. Ziemba, "The holistic and systems approach to the sustainable information society," Journal of Computer Information Systems, vol. 54 no. 1, pp. 106-116, 2013.

[58] E. Ziemba, T. Papaj and D. Descours, "Factors affecting success of egovernment portals - a perspective of software quality model," in Proceedings of European Conference on eGovernment, Brasov, Spiru Haret University, 2014, pp. 252-262.

[59] PN-ISO/IEC 27001:2007, System zarządzania bezpieczeństwem informacji, PKN, Warszawa, 2007. 